\title{
Novel DNA variation of GPR54 gene in familial central precocious puberty
}

\author{
Nosrat Ghaemi ${ }^{1}$, Martha Ghahraman²,3, Samaneh Noroozi Asl ${ }^{4}$, Rahim Vakili ${ }^{1}$, Fatemeh Fardi Golyann ${ }^{2,3}$, \\ Meysam Moghbeli ${ }^{5}$ and Mohammad Reza Abbaszadegan ${ }^{3^{*}}$
}

\begin{abstract}
Background: Puberty can be considered the end point of a maturation process which is defined by the dynamic interactions of genes and environmental factors during prenatal and postnatal development. Kisspeptin/G proteincoupled receptor-54, is as an essential gatekeeper and regulator of GnRH neurons, and a key factor in initiation of puberty. Loss and gain of functional mutations in the GPR54 gene are associated with hypogonadotropic hypogonadism and precocious puberty, respectively. This study was designed to evaluate variations of GPR54 in familial precocious puberty.
\end{abstract}

Methods: Genomic DNA was extracted from peripheral whole blood of 25 subjects with familial precocious puberty. Coding exons 1-5 of the GPR54 gene were amplified by polymerase chain reaction (PCR) and the PCR products were purified and sequenced. DNA sequences were compared to the human GenBank GPR54 sequence using Sequencher sequence alignment software.

Results: We detected three different Single Nucleotide Polymorphisms (SNPs) in GPR54: rs10407968 (24A > T) in 13 subjects (52\%); rs3050132 (1091 T > A) in 16 subjects (64\%), and a novel polymorphism (492C > G) in one subject (4\%), while three subjects (12\%) had no SNPs. No mutations were found in the GPR54 gene.

Conclusions: Regarding the presence of SNPs in $88 \%$ of the subjects in this study, it is likely a relationship exists between the SNPs of the GPR54 gene and familial precocious puberty. Further research is needed to investigate this possibility, and potential functional effects of these polymorphisms.

Keywords: Familial precocious puberty, GPR54 gene, Kisspeptin, Novel SNP

\section{Background}

Puberty is a complex biological process that can be influenced by genetic, nutritional, environmental, and socioeconomic factors. Puberty is initiated by activation of pulsatile hypothalamic gonadotropin-releasing hormone (GnRH) followed by pituitary gonadotropin secretion and gonadal steroid production. Precocious puberty is defined as the development of secondary sexual characteristics before the ages 8 years in girls and 9 years in boys which is classified as gonadotropin-dependent or independent. Gonadotropin-dependent (central) precocious puberty has a striking predominance among girls, and most of the cases are considered idiopathic. Genetic factors have

\footnotetext{
* Correspondence: Abbaszadeganmr@mums.ac.ir

${ }^{3}$ Medical Genetics Research Center, Mashhad University of Medical Sciences, Mashhad, Iran

Full list of author information is available at the end of the article
}

important roles in the time of pubertal onset. In recent studies autosomal dominant transmission has been reported with incomplete sex-dependent penetrance [1], and several gene mutations that influence puberty have been identified [2]. Activating mutations in the G proteincoupled receptor, and its ligand, kisspeptin, products of the GPR54 (NM-032551) and KiSS1 genes, respectively, were identified recently as causes of central precocious puberty [3-5]. GnRH secretion mediated by kisspeptin activation of GPR54, also referred to as KiSS1R, AXOR12, and OT7T175, which is responsible for the onset of puberty $[6,7]$. The GPR54 gene, located in the vicinity of 19q13.3 and approximately $3 \mathrm{~kb}$ in length, has five exons interrupted by four introns and contains an open reading frame (ORF) of $1197 \mathrm{bps}$ encoding a protein of 398 amino acids. GPR54 is evolutionarily conserved in mammals with the similarities of GPR54 among goat, pig, bovine, and

(C) The Author(s). 2019 Open Access This article is distributed under the terms of the Creative Commons Attribution 4.0 International License (http://creativecommons.org/licenses/by/4.0/), which permits unrestricted use, distribution, and reproduction in any medium, provided you give appropriate credit to the original author(s) and the source, provide a link to the Creative Commons license, and indicate if changes were made. The Creative Commons Public Domain Dedication waiver (http://creativecommons.org/publicdomain/zero/1.0/) applies to the data made available in this article, unless otherwise stated. 
Table 1 Clinical and Homoral features of 25 patients with central precocious puberty

\begin{tabular}{|c|c|c|c|c|c|c|c|c|c|c|c|}
\hline \multirow{2}{*}{$\begin{array}{l}\text { Patient } \\
\text { No. }\end{array}$} & \multirow[t]{2}{*}{ Sex } & \multirow{2}{*}{$\begin{array}{l}\text { Initial Clinical } \\
\text { Presentation }\end{array}$} & \multirow[t]{2}{*}{ age } & \multirow{2}{*}{$\begin{array}{l}\text { Tanner } \\
\text { Stage }\end{array}$} & \multirow{2}{*}{$\begin{array}{l}\text { Bone } \\
\text { age } \\
\text { Advance } \\
\text { (years) }\end{array}$} & \multicolumn{2}{|l|}{$\mathrm{LH}$} & \multicolumn{2}{|l|}{$\mathrm{FSH}$} & \multirow[t]{2}{*}{ EST Level } & \multirow[t]{2}{*}{ Testosterone Level } \\
\hline & & & & & & Basal & After test & Basal & After test & & \\
\hline \multicolumn{12}{|c|}{ Family A } \\
\hline$A-1$ & $\mathrm{~F}$ & Thelarche & $5 y$ & 3 & 7 & 0.8 & - & 3.8 & - & 32 & - \\
\hline$A-\|$ & $\mathrm{F}$ & Thelarche & $22 m$ & 2 & 4 & 2.3 & 9.1 & 4.2 & 15 & 24 & - \\
\hline \multicolumn{12}{|c|}{ Family B } \\
\hline$B-1$ & $\mathrm{~F}$ & Thelarche+Menarche & $8 y$ & 4 & 10.5 & 2.1 & - & 2.6 & - & 36.1 & - \\
\hline$B-\|$ & $\mathrm{F}$ & Thelarche+Menarche & $8 y$ & 4 & 10.5 & 2.4 & - & 3 & - & 40 & - \\
\hline B-III & $\mathrm{F}$ & Thelarche & $8.5 \mathrm{y}$ & 2 & 11 & 1.5 & - & 4.6 & - & 24.2 & - \\
\hline \multicolumn{12}{|c|}{ Family C } \\
\hline$C-1$ & $\mathrm{~F}$ & Thelarche & $4 y$ & 3 & 5.2 & 1.2 & 8.1 & 3.1 & 8.4 & 42 & - \\
\hline$C-I I$ & M & Testicular enlargement & $7 y$ & 2 & 9 & 2.1 & - & 6 & - & - & 116 \\
\hline \multicolumn{12}{|c|}{ Family F } \\
\hline $\mathrm{F}-\mathrm{I}$ & $\mathrm{F}$ & Thelarche & $6.2 y$ & 2 & 8.5 & 1.8 & - & 4.2 & - & 36 & - \\
\hline$F-\|$ & $\mathrm{F}$ & Thelarche & $5.3 y$ & 2 & 8 & 2.6 & - & 4.1 & - & 42 & - \\
\hline \multicolumn{12}{|c|}{ Family G } \\
\hline $\mathrm{G}-1$ & $\mathrm{~F}$ & Thelarche & $6.5 y$ & 2 & 9 & 2.3 & - & 6.1 & - & 26 & - \\
\hline G-II & $\mathrm{F}$ & Thelarche & $4.2 y$ & 2 & 6.4 & 4.1 & - & 5.9 & - & 32 & - \\
\hline \multicolumn{12}{|c|}{ Family H } \\
\hline $\mathrm{H}-\mathrm{I}$ & $\mathrm{F}$ & Thelarche+Menarche & $6 y$ & 4 & 10.5 & 3.2 & - & 6.1 & - & 42 & - \\
\hline $\mathrm{H}-\mathrm{II}$ & $\mathrm{F}$ & Thelarche+Menarche & $7 y$ & 4 & 11 & 2.9 & - & 5.4 & - & 36 & - \\
\hline \multicolumn{12}{|c|}{ Family I } \\
\hline$|-|$ & $\mathrm{F}$ & Thelarche & $4 y$ & 2 & 6.2 & 1.8 & - & 3.2 & - & 26 & - \\
\hline$|-| \mid$ & $\mathrm{F}$ & Thelarche & $5 y$ & 2 & 7.1 & 2.1 & - & 2.61 & - & 30 & - \\
\hline \multicolumn{12}{|c|}{ Family K } \\
\hline K-I & $\mathrm{F}$ & Thelarche & $7 y$ & 2 & 9.5 & 2.1 & - & 6.2 & - & 22 & - \\
\hline K-II & $\mathrm{F}$ & Thelarche & $7 y$ & 2 & 10 & 3.8 & - & 8.1 & - & 41 & - \\
\hline \multicolumn{12}{|c|}{ Family L } \\
\hline$L-I$ & $\mathrm{~F}$ & Thelarche & $5 Y$ & 2 & 8.1 & 1.2 & 6.9 & 3.1 & 17.9 & 46 & - \\
\hline$L-\|$ & $\mathrm{F}$ & Thelarche & $6.5 Y$ & 3 & 9.5 & 2.8 & 8.1 & 4.8 & 15.3 & 31 & - \\
\hline \multicolumn{12}{|c|}{ Family M } \\
\hline$M-I$ & $\mathrm{~F}$ & Thelarche & 6 & 2 & 8 & 2.3 & - & 4.1 & - & 26 & - \\
\hline$M-I I$ & $\mathrm{~F}$ & Thelarche & 5 & 3 & 7.5 & 1.4 & - & 3.6 & - & 28 & - \\
\hline \multicolumn{12}{|c|}{ Family N } \\
\hline $\mathrm{N}-\mathrm{I}$ & $\mathrm{F}$ & Thelarche & 7 & 3 & 9.5 & 3.6 & - & 4.1 & - & 41 & - \\
\hline $\mathrm{N}-\mathrm{II}$ & $\mathrm{F}$ & Thelarche & 7 & 3 & 8.7 & 2.8 & - & 3.9 & - & 31 & - \\
\hline \multicolumn{12}{|c|}{ Family O } \\
\hline O-I & $\mathrm{F}$ & Thelarche & 7 & 2 & 9.2 & 1.4 & - & 3.1 & - & 28 & - \\
\hline O-II & $\mathrm{F}$ & Thelarche & 5.5 & 3 & 7 & 1.2 & - & 4.9 & - & 32 & - \\
\hline
\end{tabular}

sheep higher than those of other mammalian species, such as human, rat, and mouse [8,9]. Kisspeptin is a relatively recent discovery in hormonal control of reproduction [10, 11]. Activation of GPR54 is apparently sufficient to trigger the neuro-endocrine events leading to the onset of puberty [12]. The aim of present study was to assess the incidence of genetic variations in GPR54 gene for the first time in Iranian familial cases with precocious puberty. We evaluated 225 patients with central precocious puberty and 


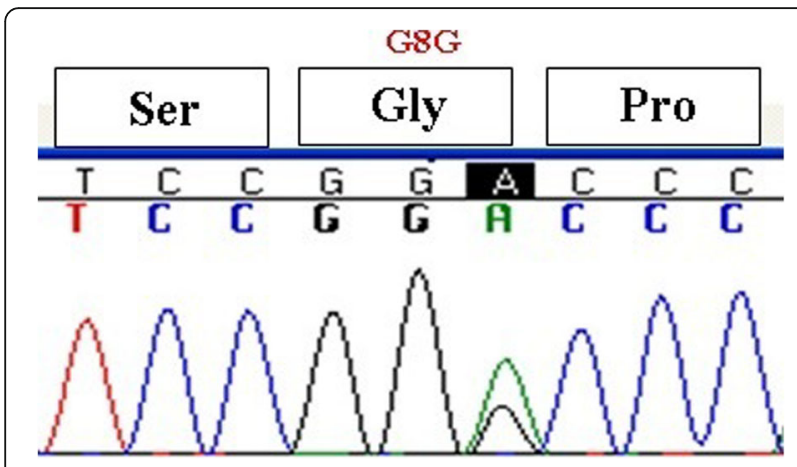

Fig. 1 The synonymous polymorphism changing A to $G$ at nucleotide 24 (rs10407968)

selected 25 subjects with familial central precocious puberty for GPR54 gene mutation studies.

\section{Methods}

We assessed 25 subjects with familial central precocious puberty (CPP) who were recruited from the pediatric department of Imam Reza hospital. The study protocols were approved by the Ethics Committee for Human Research of the Mashhad University of Medical Sciences. CPP was diagnosed according to the following criteria: Breast development before the age of 8 years in girls and testicular enlargement before the age of 9 years in boys were assessed by the pediatric endocrinologist according to the Tanner Staging System. Advanced bone age more than one year above the chronological age was measured via the Greulich and Pyle method. Increased gonadotropin levels including luteinizing hormone (LH) greater than $4.5 \mathrm{mIU} / \mathrm{mL}$, follicle stimulating hormone (FSH) greater than $7 \mathrm{mIU} / \mathrm{mL}$, and $\mathrm{LH} / \mathrm{FSH}$ ratio greater than one were observed. The Immune Radiometric Assay method (IRA) was used to measure hormone levels. $\mathrm{GnRH}$ stimulation tests were performed according to clinical findings and hormone levels; they were

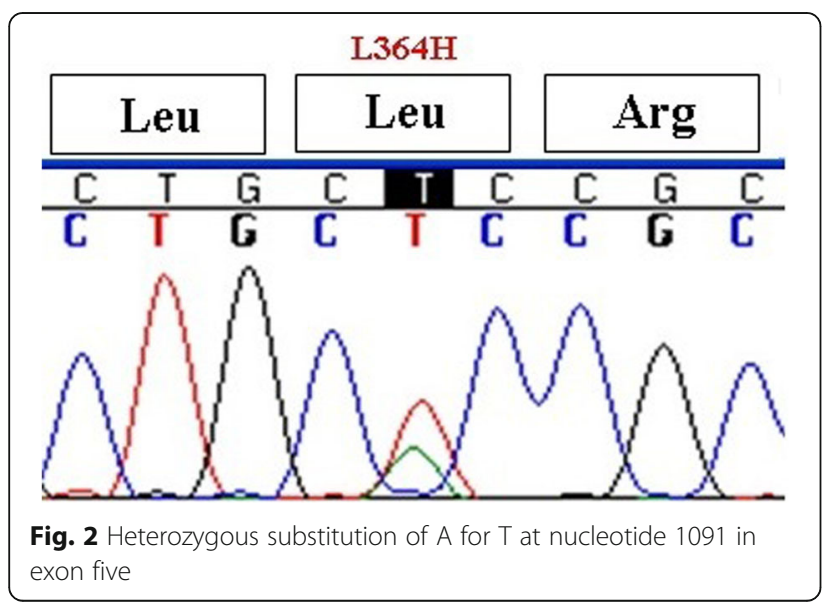

compared to age-related reference levels: estradiol greater than $20 \mathrm{pg} / \mathrm{mL}$ and testosterone greater than $300 \mathrm{ng} / \mathrm{dL}$. Gonadal sonographic findings compatible with pubertal stage: in females, uterus and ovary sizes greater than $40 \mathrm{~mm}$ and $25 \mathrm{~mm}$, respectively, and in males, testis lengths and volumes greater than $30 \mathrm{~mm}$ and $3 \mathrm{cc}$, respectively. Inclusion criteria included presence of another CPP case in the family, age of the first menstruation under 10 years old in the first-degree relative's female, and the age of the first complete face shaving before 13 years old in the first-degree relative's male. To exclude possible brain abnormalities, magnetic resonance imaging was performed in females under five years and all males. Moreover, the cases with adrenal hyperplasia, CNS tumor, and ovarian cyst were also excluded from the present study. After the confirmation of CPP, we selected 25 subjects with familial CPP (Table 1). Genomic DNA was extracted from peripheral whole blood of these subjects [13]. The coding exons $1-5$ and intron/exon boundaries of GPR54 were amplified by polymerase chain reaction (PCR) using a combination of five primer pairs. PCR products were assessed for the size and purity by separation on $2 \%$ agarose gel electrophoresis and products were purified using a DNA Gel Extraction Kit (INVITEK) according to the manufacturer's protocol. Bidirectional sequencing of purified amplicons was performed using an Applied Biosystems ABI 3730 XL automated DNA Sequencer. The sequences were compared to the human GenBank sequence for GPR54 using Sequencher sequence alignment software (Version 4.10.1).

\section{Results}

The mean age of our subjects at diagnosis was $5.76 \pm 1.2$ years old. Two subjects were twins, and two females first menstruated at 5 and 7 years old. Most subjects had siblings with precocious puberty and the rest of them had family histories of CPP in the first cousins. Height and weight at diagnosis was above the 75th percentile for age, and bone age was advanced in all subjects $(7.2 \pm 1.5$ year). All of the girls had breast and hair development with mean Sexual Maturity Ratings (SMRs) at stages of $2-3$. In 23 subjects, mean LH and FSH concentrations were $6 \pm 1.3 \mathrm{mIU} / \mathrm{mL}$ and $9.5 \pm 2.2 \mathrm{mIU} / \mathrm{mL}$, respectively. The GnRH stimulation test was performed in two subjects, and FSH and $\mathrm{LH}$ were 29 and $7.8 \mathrm{mIU} / \mathrm{mL}$, respectively. Sonographic findings were compatible with puberty in all subjects. Although, there wasn't any mutation in GPR54, three different SNPs were detected. The synonymous polymorphism changing $A$ to $G$ at nucleotide 24 (rs10407968) was observed in 52\% (13/25) of the subjects (Fig. 1). Rs3050132 is also a heterozygous substitution of $\mathrm{A}$ for $\mathrm{T}$ at nucleotide 1091 in exon 5, resulting in substitution of leucine to histidine at codon 364 

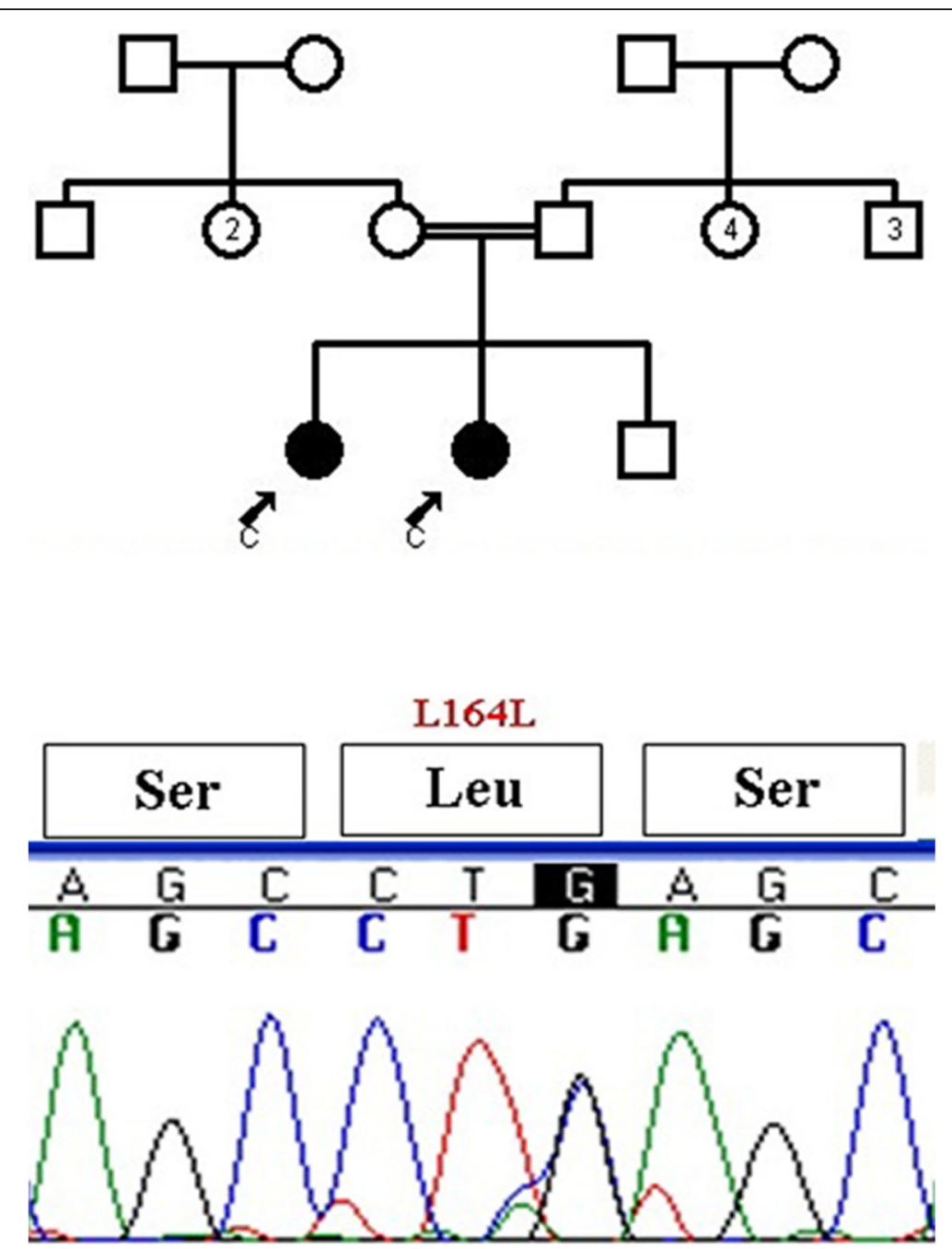

Fig. 3 Synonymous 492 C to G SNP was detected for the first time as a novel polymorphism

which was observed in $64 \%(16 / 25)$ of the cases (Fig. 2). Synonymous 492 C to G SNP was also detected for the first time as a novel polymorphism in one subject (Fig. 3). Generally, SNPs were identified in 22 subjects $(88 \%)$ and 8 out of these 22 cases (32\%) had two different SNPs. No SNPs were detected in exons 3 or 4.

\section{Discussion}

Gonadotropin-dependent CPP is caused by early maturation of the hypothalamic pituitary gonadal axis, which mimics physiological pubertal development at younger than normal ages and leads to the development of secondary sexual characteristics, acceleration of linear growth, advanced bone age, premature epiphyseal closure, and short stature [14]. The condition occurs 5-10-fold more frequently in girls than boys and most sexual precocity in girls is idiopathic [15]. The fact that family members share similar patterns of puberty and ages of onset suggests that genetic factors have roles in the pathogenesis of the pubertal process [16]. Pubertal timing is strongly influenced by genetic, however no single involved gene has been detected. The genetic regulation of pubertal onset most likely results from the additive effect(s) of multiple genes, but monogenic causes of idiopathic CPP likely exist, as cases of familial ICPP have been reported. Mutations in KiSS1 and KiSS1R affect puberty onset and GnRH secretion, and could cause monogenic ICPP [17]. Although, GnRH is the primary hormone responsible for the onset and progression of puberty, genetic factors are also important. To date, genes associated with abnormal pubertal development have been identified, and most of these result in isolated hypogonadotropic hypogonadism $[6,7,18-24]$, but they are also considered to be candidate genes in which certain mutations cause precocious puberty. To date few mutations in KiSS1 and GPR54 have been confirmed as causes of central precocious puberty [4, 22-25]. In present study GPR54 was examined for genetic variations in 25 Iranians with familial CPP. Although, 
there were not any mutations in GPR54, three different polymorphisms were detected. The rs10407968 (24 A > T) was found in $52 \%$ of subjects, rs3050132 $(109 \mathrm{~T}>\mathrm{A})$ was found in $64 \%$ of the subjects, and a novel SNP $(492 \mathrm{C}>\mathrm{G})$ was found in one subject. Rs10407968 (c.24A > G) and rs3050132(c.1091 T > A) polymorphisms have been identified in other ethnic groups [20], whereas the c.492C > G (p.L164 L) has not been previously reported. The KO JM et al. study of 101 Korean girls with central precocious puberty revealed four polymorphisms. Two of these, C.196 $\mathrm{C}>\mathrm{T}$ in GNRH1 and C.546 T > C in GNRH2, were novel [2]. Another report from Korea on non-familial girls showed seven polymorphisms and a $(c .1091 \mathrm{~T}>\mathrm{A})$ missense mutation. This missense variant induces amino acid substitution of p.Leu364His [26]. We found polymorphisms in $88 \%$ of our subjects. We think the rate of polymorphism in familial precocious puberty may be increa sed. To our knowledge, this study was the first evaluation of familial CPP and also the first study of CPP in the Iranian population. Our subjects were limited in number because we selected patients with CPP who had a sibling or first cousin with precocious puberty. In the Luan study of 272 Chinese girls with central precocious puberty, eight polymorphisms were identified and only one of these $(12.5 \%)$ was novel [27], but novel polymorphism found in our study was $30 \%$ of all detected polymorphisms which may be due to the familial histories.

\section{Conclusion}

The GPR54 gene has a key role in the puberty process. It has been hypothesized that most of mutations in this gene are lethal; consequently we expected to find no mutations in GPR54. We identified SNPs in $88 \%$ of the subjects in this study, and $32 \%$ had two polymorphisms. It is likely a relationship exists between the SNPs and GPR54 gene function, affecting familial central precocious puberty. This hypothesis needs further investigation on a larger sample size.

\section{Abbreviations}

CPP: Central precocious puberty; FSH: Follicle stimulating hormone: GnRH: Gonadotropin-releasing hormone; ICPP: Idiopathic central precocious puberty; IRA: Immune Radiometric Assay method; LH': Luteinizing hormone; ORF: Open reading frame; PCR: Polymerase chain reaction; SNPs: Single Nucleotide Polymorphisms

\section{Acknowledgements}

We gratefully acknowledge the contribution of the scientific collaborators of the Human Genetics Department of Bu Ali Research Institute of Mashhad University of Medical Sciences.

\section{Funding}

None.

\section{Availability of data and materials}

The datasets used and/or analyzed during the current study are available from the corresponding author on reasonable request.

\section{Authors' contributions}

$N G, M G, M M$, and FFG were involved in experiments and drafting. SNA and RV were involved in sample gathering. MRA supervised the project. All the authors have read and confirmed the contents of manuscript.

\section{Ethics approval and consent to participate}

All the participants (legal guardians) have filled informed consent forms which were approved by the ethic committee of Mashhad University of Medical Sciences.

\section{Consent for publication}

Not applicable.

\section{Competing interests}

The authors declare that they have no competing interests.

\section{Publisher's Note}

Springer Nature remains neutral with regard to jurisdictional claims in published maps and institutional affiliations.

\section{Author details}

'Department of Pediatric Endocrinology and Metabolism, Imam Reza Hospital, School of Medicine, Mashhad University of Medical Sciences, Mashhad, Iran. ${ }^{2}$ Immunology Research Center, Mashhad University of Medical Sciences, Mashhad, Iran. ${ }^{3}$ Medical Genetics Research Center, Mashhad University of Medical Sciences, Mashhad, Iran. ${ }^{4}$ Department of Pediatric, Valiasr Hospital, Birjand University of Medical Sciences, Birjand, Iran. ${ }^{5}$ Department of Modern Sciences and Technologies, Faculty of Medicine, Mashhad University of Medical Sciences, Mashhad, Iran.

Received: 3 September 2018 Accepted: 3 January 2019

Published online: 11 January 2019

\section{References}

1. de Vries L, Kauschansky A, Shohat M, Phillip M. Familial central precocious puberty suggests autosomal dominant inheritance. J Clin Endocrinol Metab. 2004;89(4):1794-800

2. Ko JM, Lee HS, Hwang JS. KISS1 gene analysis in Korean girls with central precocious puberty: a polymorphism, p.P110T, suggested to exert a protective effect. Endocr J. 2010;57(8):701-9.

3. Feng T, Zhao YZ, Chu MX, Zhang YJ, Fang L, Di R, et al. Association between sexual precocity and alleles of KISS-1 and GPR54 genes in goats. Anim Biotechnol. 2009;20(3):172-6.

4. Silveira LG, Noel SD, Silveira-Neto AP, Abreu AP, Brito VN, Santos MG, et al. Mutations of the KISS1 gene in disorders of puberty. J Clin Endocrinol Metab. 2010;95(5):2276-80.

5. Teles MG, Bianco SD, Brito VN, Trarbach EB, Kuohung W, Xu S, et al. A GPR54-activating mutation in a patient with central precocious puberty. N Engl J Med. 2008;358(7):709-15.

6. de Roux N, Genin E, Carel JC, Matsuda F, Chaussain JL, Milgrom E. Hypogonadotropic hypogonadism due to loss of function of the KiSS1derived peptide receptor GPR54. Proc Natl Acad Sci U S A. 2003;100(19): 10972-6.

7. Semple RK, Achermann JC, Ellery J, Faroogi IS, Karet FE, Stanhope RG, et al. Two novel missense mutations in g protein-coupled receptor 54 in a patient with hypogonadotropic hypogonadism. J Clin Endocrinol Metab. 2005;90(3):1849-55.

8. Cao GL, Chu MX, Fang L, Feng T, Di R, Li N. Analysis on DNA sequence of GPR54 gene and its association with litter size in goats. Mol Biol Rep. 2011; 38(6):3839-48

9. Muir Al, Chamberlain L, Elshourbagy NA, Michalovich D, Moore DJ, Calamari A, et al. AXOR12, a novel human G protein-coupled receptor, activated by the peptide KiSS-1. J Biol Chem. 2001;276(31):28969-75.

10. de Vries L, Shtaif B, Phillip M, Gat-Yablonski G. Kisspeptin serum levels in girls with central precocious puberty. Clin Endocrinol. 2009;71(4):524-8.

11. Irwig MS, Fraley GS, Smith JT, Acohido BV, Popa SM, Cunningham MJ, et al. Kisspeptin activation of gonadotropin releasing hormone neurons and regulation of KiSS-1 mRNA in the male rat. Neuroendocrinology. 2004;80(4): 264-72.

12. Seminara SB, Crowley WF Jr. Kisspeptin and GPR54: discovery of a novel pathway in reproduction. J Neuroendocrinol. 2008;20(6):727-31. 
13. Miller SA, Dykes DD, Polesky HF. A simple salting out procedure for extracting DNA from human nucleated cells. Nucleic Acids Res. 1988;16(3): 1215.

14. Luan X, Yu H, Wei X, Zhou Y, Wang W, Li P, et al. GPR 54 polymorphism in Chinese girls with central pre cocious puberty. Neuro endocrinology. 2007; 86(2):77-83.

15. Kakarla N, Bradshaw KD. Disorders of pubertal development: precocious puberty. Semin Reprod Med. 2003;21 (4):339-51.

16. Garibaldi L, kliegman R, Behrman R, Genson H, Stanton B. Disordors of puberty in. In: Nelson text book of pediatric 18th ed Philadelphia Saunders; 2007. p. 2309-16.

17. Tommiska J, Sorensen K, Aksglaede L, Koivu R, Puhakka L, Juul A, et al. LIN28B, LIN28A, KISS1, and KISS1R in idiopathic central precocious puberty. BMC Res Notes. 2011:4:363.

18. Seminara S, Messager S, Chatzidaki E, Thresher R, Acierno JJ, Shagoury J, et al. The GPR54 gene as a regulator of puberty. N Engl J Med. 2003;349(17): 1614-27.

19. Teles MG, Trarbach EB, Noel SD, Guerra-Junior G, Jorge A, Beneduzzi D, et al. A novel homozygous splice acceptor site mutation of KISS1R in two siblings with normosmic isolated hypogonadotropic hypogonadism. Eur J Endocrinol. 2010;163(1):29-34.

20. Tena-Sempere M. GPR54 and kisspeptin in reproduction. Hum Reprod Update. 2006;12(5):631-9.

21. Tenenbaum-Rakover Y, Commenges-Ducos M, lovane A, Aumas C, Admoni $\mathrm{O}$, de Roux N. Neuroendocrine phenotype analysis in five patients with isolated hypogonadotropic hypogonadism due to a L102P inactivating mutation of GPR54. J Clin Endocrinol Metab. 2007;92(3):1137-44.

22. Bouligand J, Ghervan C, Tello JA, Brailly-Tabard S, Salenave S, Chanson P, et al. Isolated familial hypogonadotropic hypogonadism and a GNRH1 mutation. N Engl J Med. 2009;360(26):2742-8.

23. Chan YM, de Guillebon A, Lang-Muritano M, Plummer L, Cerrato F, Tsiaras S, et al. GNRH1 mutations in patients with idiopathic hypogonadotropic hypogonadism. Proc Natl Acad Sci U S A. 2009;106(28):11703-8.

24. Zhang C, Roepke TA, Kelly MJ, Ronnekleiv OK. Kisspeptin depolarizes gonadotropin-releasing hormone neurons through activation of TRPC-like cationic channels. J Neurosci. 2008;28(17):4423-34.

25. Lanfranco F, Gromoll J, von Eckardstein S, Herding EM, Nieschlag E, Simoni M. Role of sequence variations of the GnRH receptor and G protein-coupled receptor 54 gene in male idiopathic hypogonadotropic hypogonadism. Eur J Endocrinol. 2005;153(6):845-52.

26. Oh YJ, Rhie YJ, Nam HK, Kim HR, Lee KH. Genetic variations of the KISS1R gene in Korean girls with central precocious puberty. J Korean Med Sci. 2017;32(1):108-14.

27. Luan X, Zhou Y, Wang W, Yu H, Li P, Gan X, et al. Association study of the polymorphisms in the KISS1 gene with central precocious puberty in Chinese girls. Eur J Endocrinol. 2007;157(1):113-8.

Ready to submit your research? Choose BMC and benefit from:

- fast, convenient online submission

- thorough peer review by experienced researchers in your field

- rapid publication on acceptance

- support for research data, including large and complex data types

- gold Open Access which fosters wider collaboration and increased citations

- maximum visibility for your research: over $100 \mathrm{M}$ website views per year

At $\mathrm{BMC}$, research is always in progress.

Learn more biomedcentral.com/submissions 